\title{
The Role of Anticoagulant Therapy in the Prevention of Preeclampsia Pharmacokinetic and pharmacodynamic mechanisms
}

\author{
NATALIA TURCAN ${ }^{2}$, ROXANA BOHILTEA ${ }^{1,2 *}$, ADRIAN NEACSU ${ }^{1}$, ALEXANDRU BAROS ${ }^{1,2}$, MONICA MIHAELA CIRSTOIU ${ }^{1,2}$ \\ ${ }^{1}$ Carol Davila University of Medicine and Pharmacy, 8 Eroii Sanitari Str, 050474, Bucharest, Romania \\ ${ }^{2}$ Bucharest University Emergency Hospital, 169 Splaiul Independentei, 050098, Bucharest, Romania
}

\begin{abstract}
Pregnancies complicated with preeclampsia associate a high incidence of intrauterine fetal death, intrauterine growth restriction, premature ruptures of membranes, abruption placentae and prematurity. Understanding the pathogenesis of preeclampsia is mandatory for a correct approach and prevention management of high risk cases. Placental hypoperfusion seems to be a key factor in developing systemic resounding. By placental necrosis and apoptosis, cell-free DNA is released in maternal circulation in early pregnancy, respectively prior 17 weeks of gestation. There is no test, useful in early pregnancy, accurate enough to predict preeclampsia. Various screening testhave been proposed in order to predict the development of preeclampsia, but most of them are not sufficiently accurate for general screening. There is a continuous debate regarding the algorithm of administration, doses and timing of low dose aspirin. The initiation moment is crucial, as the administration after the development symptoms and signs of preeclampsia do not interfere with the progression and the severity of the disease. Early initiation of therapy with low dose aspirin, prior the end of the first trimester is important since the pathogenesis mechanisms of preeclampsia take place in the first trimester. The action of acetylsalicylic acid consists in inhibition of COX-1 and COX-2 (cyclooxygenase isoenzymes), necessary for prostaglandin biosynthesis. Preferential inhibition of Thromboxane A2 by low dose aspirin, counterbalance the increased production of thromboxanes characteristic to preeclampsia and modulate the inflammatory process, amplified in pregnant women with preeclampsia.
\end{abstract}

Keywords: preeclampsia, prevention, aspirin.

Preeclampsia, a multisystem disorder characterized by hypertension, proteinuria and end-organ dysfunction, has a gradually or fulminant progression from nonsevere to severe forms.

The background of the clinical manifestations is the microangiopathy of vital organs: kidney, liver, brain and, respectively, placenta. The only curative treatmentremains the delivery, but preventive interventions can significantly improve maternal and fetal outcome, while avoiding important possible sequels like eclamptic seizures. Pregnancies complicated with preeclampsia associate a high incidence of intrauterine fetal death, intrauterine growth restriction, premature rupture of membranes, abruption placentae and prematurity [1]. Understanding the pathogenesis of preeclampsia is mandatory for a correctapproach and prevention management of high risk cases.

The key of the pathophysiologic process is represented by an abnormal placentation in early pregnancy resulting in placental underperfusion and ischemia with the subsequent release of a series of antiangiogenic factors. This theory is sustained by various experimental studies showing that the development of preeclampsia is impossible in the absence of placental tissue but possible in the absence of fetal tissue [2]. Also, the fact that the placental delivery is the unique and the safest existing treatment explain in large part the pathophysiological theory [3]. Systemic endothelial dysfunction resulted from impaired placentation results in impaired renal [4-7], cardiac [8-10], neurologic, hematologic [11-13], pulmonary and hepatic dysfunction. The question that remains open, is why abnormal placentation occurs only in some cases? The table 1 contains the main pathogenic factors involved in the development of preeclampsia; most probably, a combination of these factors results in an adverse pregnancy outcome.
As mentioned above, placental hypoperfusion seems to be the main factor related to systemic resounding. By placental necrosis and apoptosis, cell-free DNA is released in the maternal circulation during early pregnancy, respectively prior 17 weeks of gestation. The level of trophoblast cell-free DNA abruptly increase, about three weeks prior to clinical signs [37]. According to CondeAgudelo $A$ et al [38], urinary tract infection $[39,40]$ in pregnancy and periodontal disease are significantly related with the development of preeclampsia.

The systemic impact of preeclampsia is a result of the generalized endothelial dysfunction. This fact is objectively sustained by the laboratory findings, namely: increased levels of thrombomodulin, factor VIII antigen and circulating cellular fibronectin; Dysfunctional flowmediated vasodilation and acetylcholine mediated vasorelaxation; increased concentrations by increased production of thromboxanes and endothelin's, with vasoconstriction function and increased production of nitric oxide and prostacyclin-vasodilators [41-45].

\section{Preeclampsia-prediction}

There is no useful test in early pregnancy, accurate enough to predict preeclampsia. Identifying incipientsigns and symptoms of preeclampsia can improve the outcome by a specific management, but the cure remains only the delivery. Therefore, early identification of high risk cases, can offer the possibility of a prevention strategy.

There are several essential key points for an early diagnosis and for identifying the cases at high-risk for preeclampsia. Routine blood pressure measurement in pregnancy is accessible and allow an early diagnosis and management of preeclampsia symptoms [46]. There are several risk factors, that can be easily identified at first prenatal visit, that are statistically related with the development of preeclampsia $[47,48]$ : 
Table 1

PATHOGENIC FACTORS OF PREECLAMPSIA

\begin{tabular}{|c|c|}
\hline Abnormal remodeling of spiral arteries & $\begin{array}{l}\text { The myometrial segment is not penetrated by the cytotrophoblast cells, which } \\
\text { penetrate only the decidual portion [14] } \\
\text { Failed spiral arteries development and placental hypoperfusion [15] }\end{array}$ \\
\hline Defective trophoblast differentiation & $\begin{array}{l}\text { Absent upregulated adhesion molecule: VE-cadherin, alphav/beta3 and integrin } \\
\text { alpha1/beta1, respectively [16] } \\
\text { Absent pseudo-vasculogenesis } \\
\text { Presence of novel messenger RNAs and noncoding RNAs [17] }\end{array}$ \\
\hline Placental hypoxemia & $\begin{array}{l}\text { Comorbidities which associate vascular insufficiency (diabetes, hypertension, } \\
\text { renal disease, thrombophilia or systemic lupus erythematosus) increase the risk for } \\
\text { developing preeclampsia [18-20] } \\
\text { Obstetric conditions [21-24], with increased placental mass but with no } \\
\text { correspondently increased placental perfusion (multiple gestation, hydrops fetalis, } \\
\text { diabetes, hydatiform mole) that result in relative ischemia associate an increased } \\
\text { risk for preeclampsia [25] } \\
\text { The incidence of preeclampsia is higher in women living at high altitude } \\
\text { Late placental lesions : atherosis, thrombosis, infarction, necrosis [26] }\end{array}$ \\
\hline Immunologic factors & $\begin{array}{l}\text { Previous exposure to patemal/fetal antigens is a protective factor [27] } \\
\text { Pregnancies obtained through oocyte donation have a fourfold risk of developing } \\
\text { preeclampsia than women who have achieved pregnancy spontaneously }[28,29] \\
\text { Increased dendritic cell infiltration which results in abnormal presentation of fetal } \\
\text { and matemal antigens at the decidual level [30,31] } \\
\text { Matemal KIR-AA genotype and fetal HLA-C2 genotype have an increased risk } \\
\text { for preeclampsia } \\
\text { Increased levels of angiotensin AT-1 receptor antibodies [32] }\end{array}$ \\
\hline Genetic factors & $\begin{array}{l}\text { Family history of preeclampsia increases the risk for this pathology with two- to } \\
\text { five-fold, especially in the context of an inherited matemal STOX1 missense } \\
\text { mutation on chromosome } 10 \mathrm{q} 22 \text { [33] } \\
\text { Personal obstetrical history of preeclampsia } \\
\text { increases the risk with more than seven fold [34] } \\
\text { Fetus with trisomy } 13 \text {, with an excess of sFlt-1 and Flt-1 genes } \\
\text { Men resulted from pregnancies with preeclampsia are risk factor carriers } \\
\text { PAI-1 4G/5G polymorphism is strongly associated with preeclampsia [35] }\end{array}$ \\
\hline Environmental factors & $\begin{array}{l}\text { High body mass index, increases the risk of preeclampsia through endothelial } \\
\text { dysfunction and chronic inflammation [36] } \\
\text { Low calcium intake trough vascular or immunologic effects of calcium regulatory } \\
\text { hormones }\end{array}$ \\
\hline
\end{tabular}

High risk factors

-Autoimmune disease, like systemic lupus erythe-

matosus [49], or antiphospholipid syndrome

-Multiple gestation

-Personal history of preeclampsia

-Diabetes mellitus type one or two $[50,51]$

-Chronic hypertension [52]

-Renal disease

Moderate risk factors

-Obesity

-Family history of preeclampsia

-Over 35 years of age

-Personal history of intrauterine growth restricted fetus, long inter-pregnancy interval, history of adverse pregnancy outcome.

-Demographic factors

Various screening tests have been proposed in order to predict the development of preeclampsia, but most of them are not sufficiently accurate for general screening [53], so the detailed anamnesis remains the only pertinent predictive tool, being more sensitive than any laboratory or imaging screening test [54].

The main risk factors, associated with high pool rates and high pooled relative risks (antiphospholipid syndrome, personal history of preeclampsia, chronic hypertension) are not modifiable. Only early administration of low dose aspirin has proved so far, efficiency in preeclampsia prevention and risk reduction.

\section{Preeclampsia - prevention}

All pregnant women with high risk factors (mentioned above) for preeclampsia or at least two moderate risk factors are candidates for prophylaxis with low dose aspirin. There is a continuous debate regarding the algorithm of administration, dosage and timing of low dose aspirin. The initiation moment is crucial, as the administration after the development of preeclampsia symptoms and signs do not interfere with the progression and the severity of the disease [55].

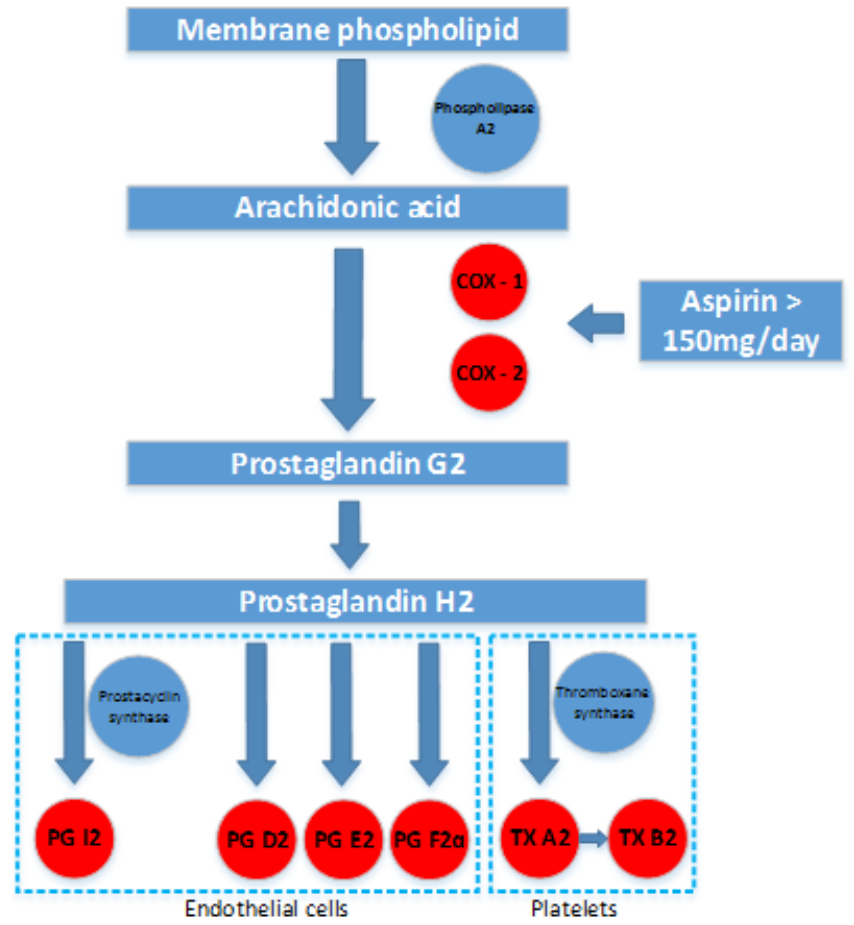

Fig 1. Effects of aspirin administration on prostaglandins production 
Early initiation of therapy with low dose aspirin, prior the end of the first trimester is important since the pathogenesis mechanisms of preeclampsia occur in the first trimester. The action of acetylsalicylic acid consists in inhibition of COX-1 and COX-2 (cyclooxygenase isoenzymes), necessary for prostaglandin biosynthesis. The production of prostacyclin and thromboxane $A 2$ is regulated by the COX-1 isoform from the vascular endothelium. Thromboxane $\mathrm{A} 2$ and prostacyclin are prostaglandins with opposite regulatory effects on plateletfunction and vascular homeostasis. Therefore, thromboxane A2 promotes platelet aggregation being also an important vasoconstrictor and on the other hand, prostacyclin is a platelet aggregation inhibitor and potent vasodilator. The second isoform, COX-2 is expressed in the presence of various inflammatory mediators or cytokines.

The targeted effect when administrating aspirin in pregnancy is the decrease of platelet synthesis of thromboxane $\mathrm{A} 2$, with no negative effect on vascular production of prostaglandins. This achievement is possible by administration of low dose aspirin (60-150 mg/day), dosage at which aspirin irreversibly acetylates COX-1. At doses higher that $150 \mathrm{mg} /$ day, both isoenzymes, COX-1 and COX-2 are inhibited and all prostaglandin production is blocked [56]. Preferential inhibition of Thromboxane A2 by low dose aspirin, counterbalance the increased production of thromboxanes characteristic to preeclampsia and modulate the inflammatory process, amplified in pregnant women with preeclampsia.

The guidelines are contradictory regarding the dose of aspirin, the indications for low and medium risk patients and the moment of initiation and interruption. Further, we will mention the most significant studies ant their recommended protocols: According to USPSTF, pregnant women with a least one major risk factor should receive low dose aspirin ( $81 \mathrm{mg} /$ day) to reduce the risk of preeclampsia, intrauterine growth restriction and preterm birth, initiated after 12 weeks of gestation until 28 weeks of gestation [57].

Society for Maternal-Fetal Medicine and The American College of Obstetricians and Gynecologists, recommend the same dose, continued daily until delivery [58]. According to ASPRE study, a greater dose of aspirin was associated with a higher reduction in risk. Thereby, according to ASPRE [59] the optimal dose is $150 \mathrm{mg}$ aspirin, initiated before 16 w eeks of gestation.

As mentioned before, placental hypoperfusion is a main characteristic of preeclampsia spectrum disorders. This fact is sustained by the morphopathological aspect of the placental tissue obtained from cases which developed preeclampsia. Respectively, characteristic of maternal vascular perfusion like placental infarcts, distal villous hypoplasia, small weight placenta, placental abruption, acute or chronic and decidual arteriopathy [60] are frequently encountered. In this context, prophylactic anticoagulation was proposed as a preventive strategy for preeclampsia in high risk cases $[61,62]$. This premise is still in debate, due to the fact that there are no large, corresponding studies with relevant data and the conclusions used as references. According to the metaanalysis conducted in 2016 regarding the administration of low-molecular weight heparin for high risk cases for preeclampsia with the prevention purpose, the incidence of preeclampsia was not influenced and the pregnancy outcome was not improved even in women with inherited thrombophilia [63]. A thing worth mentioning is that the results from single center trials contrasted totally with those obtained from multi-centric studies, meaning that studies

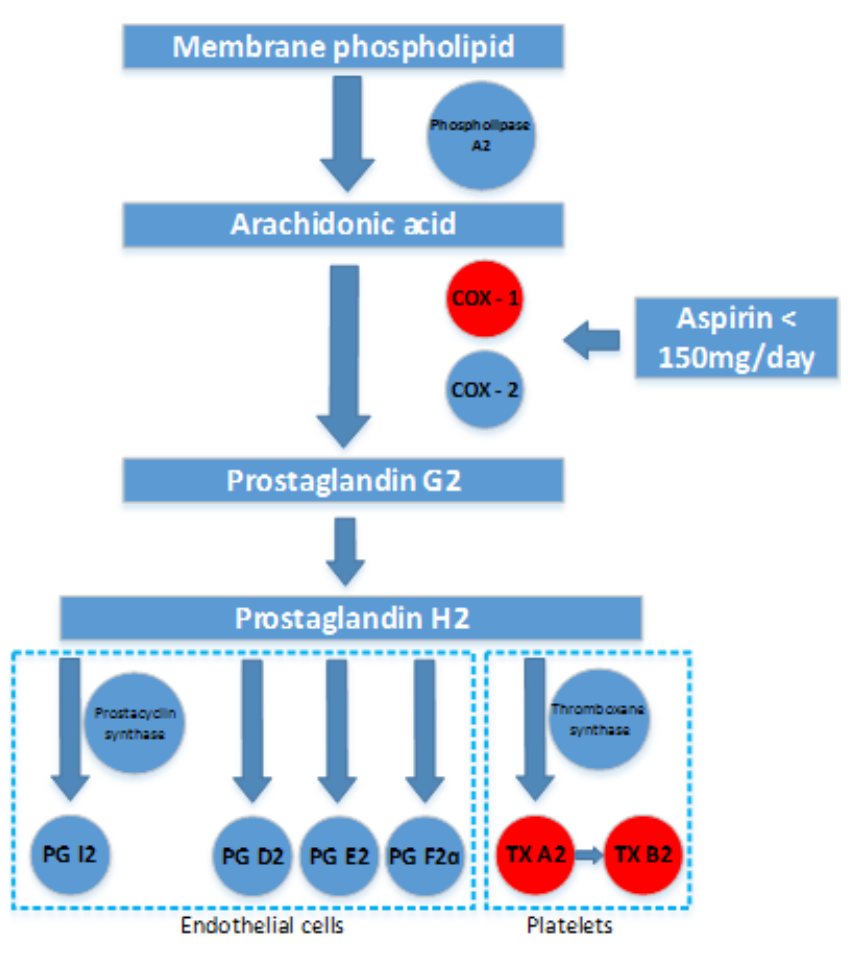

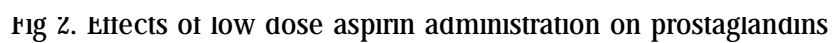
production

in this direction are still necessary in order to establish well defined indication, timing and dosage.

\section{Discussions and conclusions}

Preeclampsia, even in the presence of prevention strategies, well known and debated pathogenesis affects about $1 \%$ of all pregnancies, and a half of these cases develop severe complications and sequelae [64]. Considering the associated maternal and fetal risks and complications and no possible treatment other than delivery we will discuss further the possibility of expectant management and the limit between delivery and maternal or fetal degradation. Expectant management improve neonatal outcome with no severe maternal complications associated [65], conclusion canceled by the MEXPRE Latin Study which found that the expectant management associates a higher incidence of intrauterine growth restriction and abruption placentae with no significantly neonatal improvement [66].

According to the available data and recommendations, the correct management for a case with severe onset of preeclampsia before fetal viability is the termination of pregnancy for reducing maternal mortality and morbidity [67].

If the gestational age is between 24 and 34 weeks of gestation, expectant management may be considered in the following situations:

-Preeclampsia with transient laboratory abnormalities, respectively increased aspartate and alanine aminotransferase at twice the superior normal limit with mild thrombocytopenia (less than 100.000 cells/microL). The administration of antennal corticosteroids is indicated in this situation and repeated laboratory analysis at every 6 to $12 \mathrm{~h}$ [65], the delivery could be delayed with at least 48 hours [68].

-If preeclampsia is characterized by only high blood pressure, the use of antihypertensive drugs is indicated for severe cases and the pregnancy can be prolonged in the context of a reassuring fetal test $[65,69]$. The antihypertensive drugs do notinterfere with the progression of preeclampsia, do not reduce maternal mortality and 
morbidity, can mask an acute onset of the disease and diminish uteroplacental perfusion [70,71]. Antihypertensive treatment is indicated only in severe cases of hypertension for stroke prevention.

Intrauterine growth restriction is not an indication for emergency pregnancy termination if all other fetal markers (amniotic fluid index, Doppler velocimetry, non-stress testing) are normal and maternal status is stable [67]. If an expectant management is considered, continuous monitoring, maternal and fetal is crucial. For pregnancies which surpassed 34 weeks of gestation, in the context of symptoms and signs of severe preeclampsia emergency delivery is indicated $[72,73]$.

\section{References}

1.BROSENS, I., PIJ NENBORG, R., VERCRUYSSE, L., ROMERO, R. Am J Obstet Gynecol, 204, 2011, p. 193.

2.MOORE-MAXWELL, C.A., ROBBOY, S.J. Gynecol Oncol, 92, 2004, p. 708.

3.MATSUO, K., KOOSHESH, S., DINC, M., et al. Am J Perinatol, 24, 2007, p. 257.

4.PERIDE, I., RADULESCU, D., NICULAE, A., ENE, V., BRATU, O.G., CHECHERITA, I.A. Med Ultrason, 18, no. 3, 2016, p. 362-369.

5.NICULAE, A., PERIDE, I., MARINESCU-PANINOPOL, A., VRABIE, C.D., GINGHINA, O., JECAN, C.R., BRATU, O.G. Rom J Morphol Embryol, 57, no. 2, 2016, p. 591-594.

6.RADULESCU, D., BALCANGIU STROESCU, A., PRICOP, C., GEAVLETE, B., NEGREI, C., BRATU, O., GINGHINA, O., VACAROIU, I. Rev Chim (Bucharest), 68, no. 1, 2017, p. 52-54.

7.NICULAE, A., PERIDE, I., VINEREANU, V., RADULESCU, D., BRATU, O.G., GEAVLETE, B.F., CHECHERITA, I.A.. Rom J Morphol Embryol, 58, no. 3, 2017,p. 1065-1068.

8.MANEA, M., DRAGOS, M., PANTEA STOIAN, A., GAMAN, M.A., GAMAN, A.M., SOCEA, B., NEAGU, T.P., STANESCU, A.M.A., BRATU, O.G., DIACONU, C.C. Rev Chim (Bucharest), 69, no. 11, 2018, p. 4180-4184. 9.DIACONU, C.C., DRAGOI, C.M., BRATU, O.G., NEAGU, T.P., PANTEA STOIAN, A., COBELSCHI, P.C., NICOLAE, A.C., IANCU, M.A., HAINAROSIE, R., STANESCU, A.M.A., SOCEA, B. Farmacia, 66, no. 3, 2018, p. 408-415.

10.DIACONU, C.C., MANEA, M., IANCU, M.A., STANESCU, A.M.A., SOCEA, B., SPINU, D.A., MARCU, D., BRATU, O.G. Rev Chim (Bucharest), 69, no. 5, 2018, p. 1071-1074.

11.SURCEL, M., HUICA, R.I., MUNTEANU, A.N., ISVORANU, G., PIRVU, I.R., CIOTARU, D., CONSTANTIN, C., BRATU, O., CARUNTU, C., NEAGU, M., URSACIUC, C. Experimental and therapeutic medicine, 17, no. 2, 2019, p. 1030-1038.

12.MARCU, R.D., SPINU, A.D., SOCEA, B., BODEAN, M.O., DIACONU, C.C., VASILESCU, F., NEAGU, T.P., BRATU, O.G. Rev Chim (Bucharest), 69, no. 4, 2018, p. 823-830.

13.BRATU, O.G., MARCU, R.D., SOCEA, B., NEAGU, T.P., DIACONU, C.C., SCARNECIU, I., TURCU, F.L., RADAVOI, G.D., BRATILA, E., BERCEANU, C., SPINU, A.D. Rev Chim (Bucharest), 69, no. 7, 2018, p. 1813-1816.

14.ZHOU, Y., DAMSKY, C.H., CHIU, K., et al. J Clin Invest, 91, 1993, p. 950.

15.PADURARU, D.N., BOUARIU, A., ION, D., DUMITRASCU, M.C., NITIPIR, C., PANTEA STOIAN, A., HAINAROSIE, R., BOLOCAN, A., ORLOV, C., BADIU, D.C., DIACONU, C., PITURU, S., ANDRONIC, 0. Romanian Biotechnological Letters, 23, no 5, 2018, p.14056-14066.

16.LIM, K.H., ZHOU, Y., JANATPOUR, M., et al. Am J Pathol, 151, 1997, p. 1809.

17.ZHOU, Y., DAMSKY, C.H., FISHER, S.J . J Clin Invest, 99, 1997, p. 2152.

18.STANESCU, A.M.A., GRAJ DEANU, I.V., IANCU, M.A., PANTEA STOIAN, A., BRATU, O.G., SOCEA, B., SOCEA, L.I., DIACONU, C.C. Rev Chim (Bucharest), 69, no. 7, 2018, p. 1668-1672.

19.ROBERTSON, W.B., BROSENS, I., DIXON, H.G. J Pathol Bacteriol, 93, 1967, p. 581.
20.BOHILTEA, R.E., TURCAN, N., MURESIAN, H., CONDU, S., BRATILA, E., CIRSTOIU, M.M. Maedica, 11, no. 3, 2016, p. 241-244.

21.STANIMIR, M., CHIUTU, L.C., WESE, S., MILULESCU, A., NEMES, R.N., BRATU, O. Rom J Morphol Embryol, 57, no. 2 (Suppl), 2016, p. 849-852.

22.BODEAN, O., BRATU, O., BOHILTEA, R., MUNTEANU, O., MARCU, D., SPINU, D.A., VACAROIU, I.A., SOCEA, B., DIACONU, C.C., FOMETESCU GRADINARU, D., CIRSTOIU, M. Rev Chim (Bucharest), 69, no. 6, 2018, p. 1411-1415.

23. TATARU, A.L., FURAU, G., AFILON, J., IONESCU, C., DIMITRIU, M., BRATU, O.G., TIT, D.M., BUNGAU, S., FURAU, C. J. Clin. Med, 8, no. 1, 2019, E96; https://doi.org/10.3390/jcm8010096.

24.MEHEDINTU, C., ANTONOVICI, M., BRINDUSE, L., BRATILA, E., STANCULESCU, R., BERCEANU, C., BRATU, O., PITURU, S., ONOFRIESCU, M., MATASARIU, D.R. Rev Chim (Bucharest), 69, no. 3, 2018, p. 581-584.

25.PALMER, S.K., MOORE, L.G., YOUNG, D., etal. Am J Obstet Gynecol, 180, 1999, p. 1161.

26.KHONG, T.Y., DE WOLF, F., ROBERTSON, W.B., BROSENS, I. Br J Obstet Gynaecol, 93, 1986, p. 1049.

27.ROBILLARD, P.Y., HULSEY, T.C., PERIANIN, J., et al. Lancet, 344, 1994, p. 973.

28.MASOUDIAN, P., NASR, A., DE NANASSY, J, et al. AmJ Obstet Gynecol, 214, 2016, p. 328

29.MEHEDINTU, C., BRATILA, E., BRINDUSE, L.A., CIRSTOIU, M.M., BERCEANU, C., BORDEA, A., COMANDASU, D.E., CARP VELISCU, A., BRATU, 0., SAVA, C., BUMBU, A.G. Rev Chim (Bucharest), 69, no. 12, 2018, p. 3611-3615.

30.STOICESCU, M., BUNGAU, S., TIT, D.M., MUTIU, G., PURZA, L., IOVAN, C., POP, O.L. Romanian J ournal of Morphology and Embriology, 58, no. 4, 2017, p. 1429-1434.

31.HUANG, S.J ., CHEN, C.P., SCHATZ, F., et al. J Pathol, 214, 2008, p. 328.

32.XIA, Y., WEN, H., BOBST, S., et al. J Soc Gynecol Investig, 10, 2003, p. 82.

33.MOGREN, I., HOGBERG, U., WINKVIST, A., STENLUND, H. Epidemiology, 10, 1999, p. 518.

34.DUCKITT, K., HARRINGTON, D. BMJ, 330, 2005, p. 565.

35.GIANNAKOU, K., EVANGELOU, E., PAPATHEODOROU, S.I. Ultrasound Obstet Gynecol, 51, 2018, p. 720.

36.PARE, E., PARRY, S., MCELRATH, T.F., et al. Obstet Gynecol, 124, 2014, p. 763.

37.LEVINE, R.J., QIAN, C., LESHANE, E.S., et al. Am J Obstet Gynecol, 190, 2004, p. 707.

38.CONDE-AGUDELO, A., VILLAR, J., LINDHEIMER, M. Am J Obstet Gynecol, 198, 2008, p. 7.

39.RADULESCU, A., MADAN, V., AUNGURENCI, A., BRATU, O., FARCAS, C., DINU, M., MISCHIANU, D. Romanian Journal of Military Medicine, 118 , no. 3, 2015, p. 20-22.

40.SPINU, D., BRATU, O., POPESCU, R., MARCU, D., RADULESCU, A., MISCHIANU, D. Romanian J ournal of Military Medicine, 118, no. 3, 2015, p. 12-15.

41.GRANGER, J.P., ALEXANDER, B.T., BENNETT, W.A., KHALIL, R.A. Am J Hypertens, 14, 2001, p. 178S.

42.PANTEA STOIAN, A., MITROFAN, G., COLCEAG, F., et al. Rev Chim (Bucharest), 69, no. 9, 2018, p. 2515-2519.

43.ABDEL-DAIM, M.M., ZAKHARY, N.I., ALEYA, L., BUNGAU, S.G., BOHARA, R.A., SIDDIQI, N.J . Oxidative Medicine and Cellular Longevity, 2018, ID 2098123, 2018. https://doi.org/10.1155/2018/2098123 44.ABDEL-DAIM, M.M., ABO-EL-SOOUD, K., ALEYA, L., BUNGAU, S.G., NAJDA, A., SALUJA, R. Oxidative Medicine and Cellular Longevity, 2018, ID 6276438, 2018. https://doi.org/10.1155/2018/6276438 45.SOCEA, L.I., VISAN, D.C., BARBUCEANU, S.F., APOSTOL, T.V., BRATU, O.G., SOCEA, B. Rev Chim (Bucharest), 69, no. 4, 2018, p. 795-797.

46.HENDERSON, J.T., THOMPSON, J.H., BURDA, B.U., CANTOR, A. JAMA, 317, 2017, p. 1668.

47.LEFEVRE, M.L. Ann Intern Med, 161, 2014, p. 819. 
48.PANTEA-STOIAN, A., STOICA, R.A., STEFAN, S.D. IntechOpen, DOI: 10.5772/intechopen.84569.

49.IFTIMIE, G., PANTEA STOIAN, A., SOCEA, B., MOTOFEI, I., MARCU, D., COSTACHE, R.S., DIACONU, C. Romanian Journal of Military Medicine, CXXI, no. 3, 2018, 9-15.

50.DIACONU, C., SALMEN, T., GAMAN, M.A., BRATU, O.G., MISCHIANU, D., MARCU, R.D., SUCEVEANU, A.I., COSTACHE, R.S., PANTEA STOIAN, A. Romanian J ournal of Military Medicine, CXXII, no. 1, 2019, p. 1621.

51.DIACONU, C, NASTASA, A., ZAKI, A.R., ARSALAN, M. The $2^{\text {nd }}$ International Conference on Interdisciplinary Management of Diabetes Mellitus and its Complications - Diabetes mellitus as cardiovascular disease, Interdiab 2016 Proceedings, p. 201-210. Ed. Niculescu. Editors Cristian Serafinceanu, Octavian Negoita, Viviana Elian.

52.AVRAMESCU, C., IANCU, A., DEDIU, G., DIACONU, C., MATEI, D. J ournal of Hypertension 2017;35:e322.

53.MEADS, C.A., CNOSSEN, J.S., MEHER, S., et al. Health Technol Assess, 12, 2008, p. iii.

54.*** Committee Opinion No. 638: First-Trimester Risk Assessment for Early-Onset Preeclampsia. Obstet Gynecol, 126, 2015, e25.

55.BRICENO-PEREZ, C., BRICENO-SANABRIA, L., VIGIL-DE GRACIA, P. Hypertens Pregnancy, 28, 2009, p. 138.

56.PATRONO, C. N Engl J Med, 330, 1994, p. 1287-1294.

57.LEFEVRE, M.L. Ann Intern Med, 161, 2014, p. 819.

58.*** ACOG Committee Opinion No. 743: Low-Dose Aspirin Use During Pregnancy. Obstet Gynecol, 132, 2018, e44.

59.ROLNIK, D.L., WRIGHT, D., POON, L.C., et al. N Engl J Med, 377, 2017, p. 613.

60.ERNST, L.M. APMIS, 126, 2018, p. 551.
61.LASLO, C.L., PANTEA STOIAN, A., SOCEA, B., et al. J ournal of Mind and Medical Sciences, 5, 2018, p. 195-201.

62.TICA, O.A., TICA, O., ANTAL, L., HATOS, A., POPESCU, M.I., PANTEA STOIAN, A., BRATU, O.G., GAMAN, M.A., PITURU, S.M., DIACONU, C.C. Farmacia, 66, no. 6, 2018, p. 972-976.

63.AREIA, A.L., FONSECA, E., AREIA, M., MOURA, P. Arch Gynecol Obstet, 293, 2016, p. 81.

64.HNAT, M.D., SIBAI, B.M., CARITIS, S., et al. Am J Obstet Gynecol, 186, 2002, p. 422.

65.SIBAI, B.M., MERCER, B.M., SCHIFF, E., FRIEDMAN, S.A. Am J Obstet Gynecol, 171, 1994, p. 818.

66.VIGIL-DE GRACIA, P., REYES TEJ ADA, 0., CALLE MINACA, A., et al. Am J Obstet Gynecol, 209, 2013, p. 425. e1.

67.ACOG Practice Bulletin No. 202: Gestational Hypertension and Preeclampsia. Obstet Gynecol, 133, 2019, el.

68.BADIU, D.C, SIMA, M.R., MEHEDINTU, C. et al. Journal of Mind and Medical Sciences, 5, 2018, p.158-162.

69.DIACONU, C.C., DEDIU, G.N., IANCU, M.A. Acta Cardiologica, 73, 2018, p. 511-517.

70.SIBAI, B.M. N Engl J Med, 335, 1996, p. 257.

71.DIACONU, C.C., STANESCU, A.M.A., PANTEA STOIAN, A., TINCU, R.C., COBILINSCHI, C., DRAGOMIRESCU, R.I.F., SOCEA, B., SPINU, D.A., MARCU, D., SOCEA, L.I., BRATU, O.G. Rev Chim (Bucharest), 69, no. 6, 2018, p. 1367-1370.

72.BOHILTEA, R., TURCAN, N., IONESCU, C., et al. 5th Romanian Congress of the Romanian Society of Ultrasound in Obstetrics and Gynecology, 2017, p. 105-112.

73.DIACONU, C., BALACEANU, A., BARTOS, D. Central European Journal of Medicine, 8, 2013, pp. 548-552.

Manuscript received: 21.09 .2018 